\title{
Exploring the Strength of the Process Writing Approach as a Pedagogy for Fostering Learner Autonomy in Writing Among Young Learners
}

\author{
Marine Yeung ${ }^{1}$ \\ ${ }^{1}$ School of Arts and Humanities, Tung Wah College, Hong Kong \\ Correspondence: Marine Yeung, School of Arts and Humanities, Tung Wah College, 90A, Shantung Street, \\ Mongkok, Kowloon, Hong Kong.
}

Received: June 30, 2019 Accepted: August 6, 2019 Online Published: August 9, 2019

doi: 10.5539/elt.v12n9p42 URL: https://doi.org/10.5539/elt.v12n9p42

\begin{abstract}
Learner autonomy is widely recognized as a desirable educational goal in second or foreign language learning. However, the generality of the concept often makes it difficult to either nurture or measure the related traits. The present study focused on learner autonomy in the area of writing, exploring the use of the process approach as a means to foster its development in terms of students' emerging writing skills. The study was conducted in the naturalistic settings of three secondary school ESL writing classrooms in Hong Kong involving 70 student participants. Data gathered quantitatively with a questionnaire and qualitatively through self-assessment forms, learners' journals and case studies suggest that the process approach can reduce students' reliance on the teacher and their tendency to seek help from others, while leading to growth in their metacognitive knowledge about writing and their knowledge of themselves as writers. These developments are all signs of the emergence of learner autonomy in these young ESL writers. Overall, the findings suggest that the process approach can bring about similar changes in young writers despite variations in the cultural backgrounds and teaching beliefs of its implementers. It is argued that the strength of the process approach may lie in the stimulation of the growth of autonomous skills and attitudes in writing in young learners, and such a strength should be recognized by language educators who view learner autonomy as a major educational goal.
\end{abstract}

Keywords: second language writing, process approach, learner autonomy, ESL learners, secondary schools, writing pedagogy

\section{Introduction}

\subsection{The Desirability of Learner Autonomy}

The development of learner autonomy is generally considered to be an important goal in the field of education. Autonomy is essential for second language learners, especially in terms of their development of writing skills. Bitchener and Ferris (2012) suggest that student writers need to "build awareness, knowledge, and strategic competence so that they can develop skills to better monitor their own writing in the future" (p. 140) and thus become effective and autonomous writers. The question is: how can we foster autonomy in terms of students' development of their writing skills?

Many researchers argue that writing has excellent potential for developing the kinds of awareness essential to learner autonomy. According to Little (1997), to achieve autonomy as learner-users of a second language, we need to develop both language awareness in the psycholinguistic sense and language awareness as externally derived knowledge about language - the former underpinning spontaneous language use and the latter providing the means to reflect analytically on our target language as a rule-governed system and medium of communication. Reflective and communicative writing tasks can create a pedagogical interface between these two kinds of awareness. Little considered that the success of Dam (1995) and Thomsen (Thomsen \& Gabrielsen, 1991) in boosting students' language proficiency and autonomy in their English classrooms was related to the important role they assigned to writing reflective and communicative texts.

Even if writing activities are not purposefully manipulated to foster learner autonomy, outcomes conducive to learner autonomy may still result as by-products of the processes involved in learning to write. A study on the outcomes of EFL academic writing courses conducted by Katznelson, Perignan and Rubin (2001) revealed a 
wide range of perceived changes in writers along with changes with their writing, including the ability to use on-line Internet writing tools, the development of a more critical perspective, and affective outcomes such as increased self-esteem. These findings suggest that writing does have the potential for fostering skills and attitudes that may be fundamental to autonomous learning. This study therefore set out to explore the impact of writing instruction on the development of learner autonomy in terms of students' writing skills.

\subsection{The Process Writing Approach and the Development of Autonomy}

Among various approaches to teaching and learning writing, the process approach theoretically holds the greatest potential in encouraging the development in learner autonomy. In practice, the process approach brings the student writer through the process of pre-writing, drafting, revision and editing. Peer feedback, teacher feedback and self-evaluation are integral aspects of the composing process and may play an important part in developing autonomous writers (Hyland, 2000). Although there are those who have pointed out the multiplicity of process theories and the lack of consensus as to what constitutes the paradigm (Matsuda, 2003), at the heart of the process approach is a "non-linear, exploratory, and generative process whereby writers discover and reformulate their ideas as they attempt to approximate meaning" (Zamel, 1983). Advocates of process pedagogy emphasize the importance of teaching writing not as a product but as process: of helping students discover their own voice; of recognizing that students have something important to say; of allowing students to choose their own topic; of providing teacher and peer feedback; of encouraging revision; and of using student writing as the primary text of the course (Matsuda, 2003). Casanave (2004) has also pointed out that process pedagogies help novice writers understand the roles of invention, planning, discovery, and revising and the inevitable role of errors and problems with logic during the overall process of composing.

Therefore, although there is little hard evidence that process pedagogies actually lead to significantly better writing in L2 contexts, some (e.g., Hyland, 2002, 2003) argue that the strength of process pedagogy may lie in its acknowledgement of the cognitive dimensions of writing and the potential it has for fostering such autonomous attitudes and skills as self-discovery, self-reflection and inner-directed exploration. This view about the true merit of the process approach has found some support in research. For example, Curtis (2001) found that student teachers benefited from the approach in terms of their self-confidence as writers, and Cresswell's (2000) study showed that university students trained to self-monitor their writing in a multiple-draft process writing programme could self-articulate their concerns in composing and paid more attention to content and organization. These studies, however, were mainly conducted among more proficient learners at university level or above; more importantly, they did not set out to focus on the development of learner autonomy in learners. The present study therefore adapted this approach for young ESL learners and explored its potential effects exclusively from the perspective of learner autonomy development.

\subsection{Defining and describing an Autonomous Writer}

In order to investigate the impact of the process approach on these younger learners, we need to answer an important question - what do we mean by an autonomous writer? While there have been diverse approaches to the conceptualization of the concept and differences in views on the components of learner autonomy (e.g., Holec, 1981; Wenden, 1991; Scharle \& Szabó, 2000; Little, 1991; Benson, 1996), the classic definition of learner autonomy by Holec (1981) is still most widely cited in the literature:

To take charge of one's own learning is to have, and to hold, the responsibility for all the decisions concerning all aspects of this learning, i.e.:

Determining the objectives;

Defining the contents and progressions;

Selecting methods and techniques to be used;

Monitoring the procedure of acquisition properly speaking (rhythm, time, place, etc.);

Evaluating what has been acquired. (Holec, 1981, p. 3).

In other words, an autonomous learner is one that can manage his or her learning effectively; an autonomous writer, by inference, is a writer or learner of writing who can demonstrate such a trait or capacity in the area of writing. In more concrete terms, an autonomous learner of writing is able to use such learning strategies as goal setting, planning for writing, making decisions on what and how to learn, self-monitoring and self-assessment. Affectively, he or she feels in control of his or her own writing, feels the need to take charge of his or her own learning by setting learning goals, choosing appropriate learning strategies and evaluating his or her own learning progress. An autonomous learner of writing thus needs to have cognitive, metacognitive and affective 
skills, knowing what to learn as well as how best to learn. This view of writer autonomy, as manifested by the writer's initiative to ask questions, seek feedback, reflect on his or her own writing and generate critical self-feedback, is elaborated by Hyland and Hyland (2006) in their discussion on the role of feedback on second language students' writing.

One problem that leads to difficulty in theorization and practice of learner autonomy is the lack of domain-specificity in research in learner autonomy. Learner autonomy is often used in a rather general sense, referring to the learner's general attitudes and skills in learning. However, an autonomous language learner may not be equally autonomous in all aspects of language learning; also, for autonomy to be accessible to learners, we must be able to show that learners can and do take control over certain aspects of their learning within natural contexts of learning (Benson, 2011). The present study therefore set out to contribute to the body of research in learner autonomy by focusing on its development in the specific area of writing.

With consideration of all the factors mentioned above, a study was carried out in three secondary school writing classrooms in Hong Kong to examine the impact of the process approach on the development of learner autonomy in the area of writing. In order to examine this, a construct of learner autonomy was developed for this study based on Oxford's (2003) taxonomy of learner autonomy.

Using an approach which Benson (2009) metaphorically called the "kaleidoscopic strategy", Oxford's (2003) taxonomy amalgamates various definitions and perspectives of learner autonomy into a "macro-definition", incorporating technical, psychological, sociocultural and political-critical perspectives on autonomy. Four important themes, namely context, agency, motivation, and learning strategies run through each of these perspectives. By embracing these various perspectives and themes, the taxonomy acknowledges learner autonomy as a multi-dimensional construct.

Taking reference from the psychological perspective of Oxford's (2003) taxonomy, which sees autonomy as a combination of characteristics of the individual, a framework of learner autonomy in writing was proposed for this study. The individual traits of motivation, self-confidence and independence from the teacher are embraced in the proposed framework as autonomous attitudes. The component of independence from the teacher, which is not directly addressed in Oxford's (2003) taxonomy, is incorporated as part of the construct because dependence on the teacher would indicate a lack of willingness to take charge of one's learning. In the literature on learner autonomy, the role of the teacher is often debated; although it is agreed that learner autonomy does not mean total independence from the teacher, there is little dispute that in order to foster the development of learner autonomy in the classroom, teachers have to learn to relinquish control to their students and "wean" their students away from teacher dependence (Sheerin, 1997, p. 63).

Another part of the framework comprises autonomous skills. Learning strategies are considered to be autonomous skills as they are often viewed as a psychological gateway to L2 learner autonomy (Dickinson, 1992; Oxford, 1990, 2003; Wenden, 1991). For the purpose of this study, mainly use of strategies for writing and the learning of writing, such as planning for writing and making self-initiated revisions, were considered. Since metacognitive knowledge has been increasingly acknowledged to be fundamentally important in self-regulated learning (e.g. Wenden, 1998; Little, 2004; 2007), it was also incorporated in the construct even though they are not highlighted in Oxford's (2003) taxonomy.

Thus, learning autonomy in writing was proposed as a construct embracing factors that constitute autonomous attitudes, including motivation, self-confidence and independence from the teacher, as well as those that constitute the enabling skills, including strategy use and its prerequisite of metacognitive knowledge. This general framework was used for the development of a questionnaire and the analysis of both the quantitative and qualitative data. With this conceptualization of learner autonomy in writing, the study sought to answer the question:

Do young ESL learners show changes that reflect development in learner autonomy in writing after being instructed in the peer-review multiple-draft process writing approach?

\section{Methodology}

\subsection{The Setting}

The study consisted of two sub-studies ("Sub-study 1" and "Sub-study 2") taking place in two schools that use Chinese as the medium of instruction (CMI), purposely selected on the basis of their representativeness of the local school context of Hong Kong. The schools that took part in the study were average local secondary schools in terms of the general academic performance of the students. At the time of the study, a local school banding system was in force; as the two participating schools fell into the middle bands rather than the highest or lowest 
bands, they were considered to represent the average secondary schools in Hong Kong. Also, since Chinese is the major medium of instruction in most secondary schools in Hong Kong, it was believed that a study carried out in CMI schools would be more relevant to the local situation.

\subsection{The Participants}

All the student participants of this study were aged between 12 and 16. Sub-study 1 was conducted in a Secondary four class of 30 students in a co-education secondary school. Sub-study 2, which is the focus of this report, took place simultaneously in two Secondary one classes (the "NET Group" and the "LET Group") with 19 and 21 students respectively in a girls' school. The participants in these two classes were all locally born and educated ethnic Chinese girls aged between 12 and 13 who spoke Cantonese as their first language. The participants in the NET Group were taught by a native English-speaking teacher (NET) who had been brought up and educated in the west while those of the LET Group were taught by a local non-native English-speaking teacher (LET). Because the two groups of student participants in Sub-study 2 were largely homogenous demographically and yet taught by two teachers of rather different cultural backgrounds, they provided a more interesting angle for comparison and were made the focus of this report.

\subsection{Research Design}

The study was conducted in the naturalistic settings of the classrooms using a simultaneous mixed method pre-experimental design where quantitative and qualitative data were collected at the same time and analyzed in a complementary manner. In each sub-study, both quantitative and qualitative data were collected for the exploration of the effects of writing instruction using the process approach. Data were collected quantitatively with a questionnaire (Appendix A) and qualitatively through the open-ended questions of the questionnaire (Appendix A), the self-assessment forms (Appendix B) from three writing tasks and writing journals. Further data were collected from several individuals from each group who participated in the case studies. The design and participants of the study are summarized in Figure 1 below.

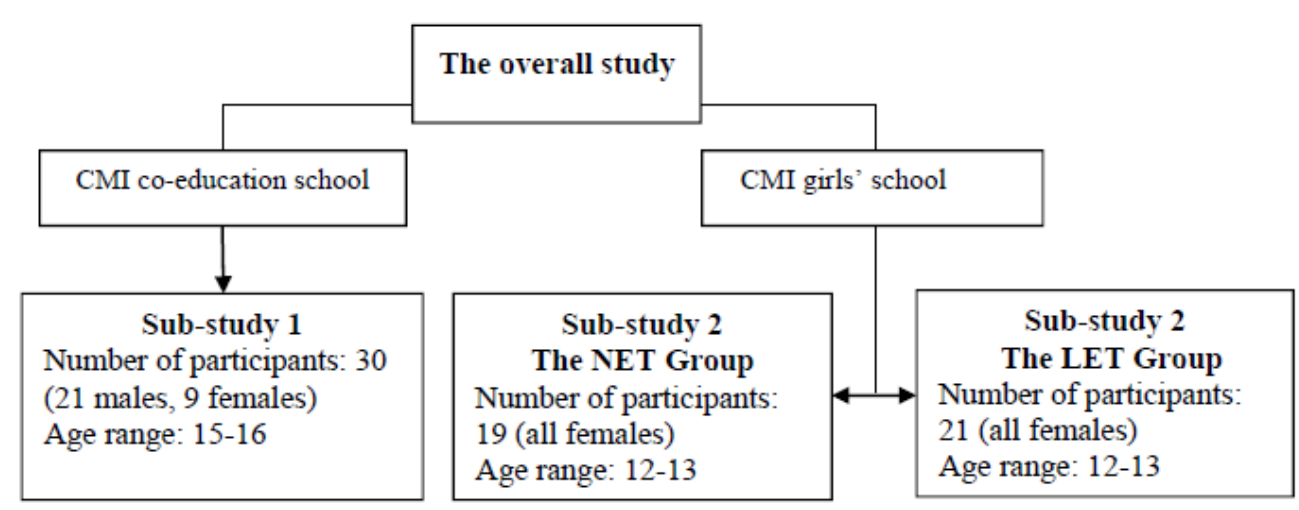

Figure 1. Design of the study

\subsection{The Writing Programme}

A process approach was adopted in the three classes over a semester (about 3 months) during which data collection was carried out. Care was taken not to prolong the intervention and data collection period in order to minimize the intervening effects associated with long-term writing development, which often displays high levels of idiosyncrasy (Sasaki, 2004). Each group completed three writing tasks over the semester, and each writing task was completed in three drafts within around a month's time. There were peer sessions between drafts, and the students were allowed to complete the drafts at home. The writing cycle is shown in Figure 2 below.

As the study was carried out in regular classrooms, writing tasks were not stipulated by the researcher but rather assigned by the teachers following the syllabus of the schools. To ensure comparability of the writing programmes, all three classes were asked to complete three consecutive writing tasks in the process approach, and each class was provided with the same revision checklist and peer and self-assessment forms for use in each writing task. 

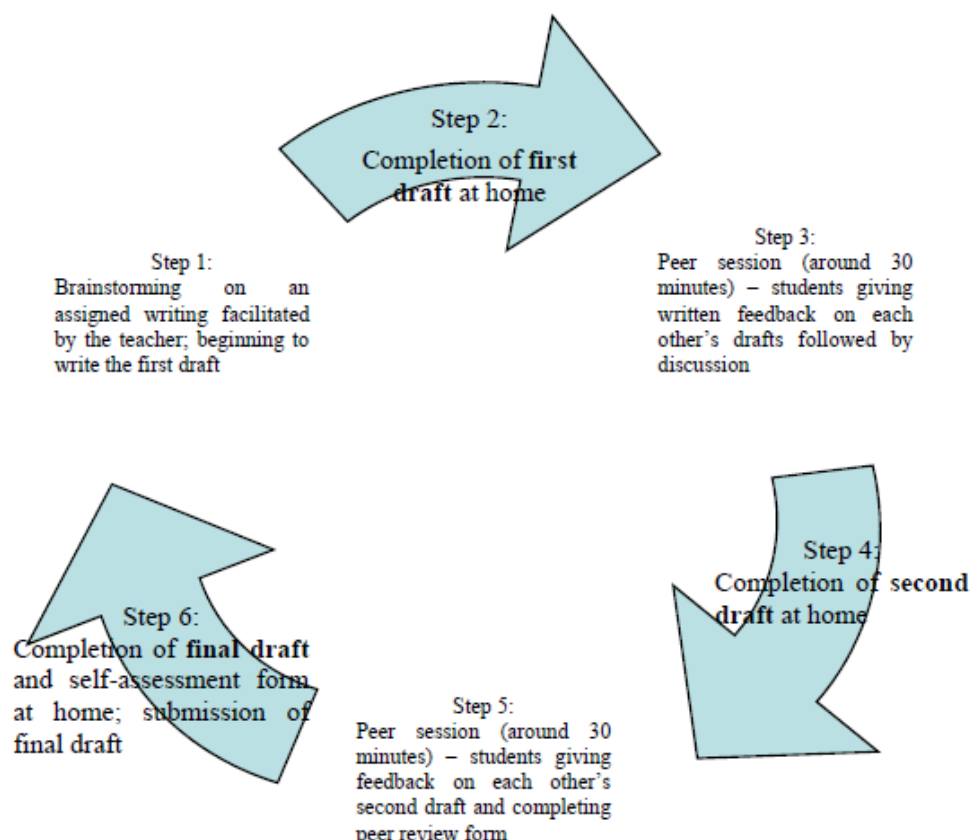

Figure 2. The process approach as adopted in the classes

\subsection{Data Collection and Analysis}

\subsubsection{Quantitative Data}

The quantitative data were collected from the student participants using a questionnaire, which was administered to the whole group twice, once before the writing programme (as the pre-test) and once after (as the post-test). The questionnaire was developed based on the conceptualization of learner autonomy in the area of writing with reference to the instrument developed by Cotterall (1995) investigating learners' readiness for autonomous learning, Oxford's (1990) Strategy Inventory for Language Learning (SILL) and the cognitive model of writing proposed by Hayes and Flower (1980) about the expert composing process, which involves such recursive steps of planning, translating and revising. As the participants of this study were young learners with limited linguistic competence in their L2, the questionnaire was translated into their L1 (Chinese) with the length of the questionnaire kept short and level of complexity kept simple. Back translation was conducted to ensure the original meaning was kept.

The questionnaire was designed with writing as the focus and included three sections with a total of 66 five-point Likert-scale questions $(1=$ strongly disagree to $5=$ strongly agree). Section 1 aimed to find out about the student's preparedness for autonomous learning, or autonomous attitudes; Section 2 and Section 3 tapped into the learner's general approach to writing and their use of strategies in the writing process and in learning writing, in other words, their autonomous skills.

The 70 completed questionnaires from the pre-test from all the groups were put together for factor analysis, a procedure used to ascertain the fundamental structure of a set of indicator items (Pedhazur \& Schmelkin, 1991). The same procedure was carried out on the data from the post-test from the same 70 student participants to ensure test-retest reliability. The factor analysis identified the following nine factors of learner autonomy in writing: Self-directedness, Motivation, Degree of Dependence on the Teacher, Peer Help and Feedback, Revision, Planning, Direct Strategies for Learning Writing, Metacognitive Strategies and Knowledge, and Social Strategy Use. After factor analysis, a paired-sample t-test was conducted on the data from each group to compare the pre-test and post-test mean scores in all the nine factors to find out if any significant changes had taken place after the writing programme.

The scaling procedure including the item-total correlations of the same nine factors identified in the pre-test and post-test as well as the results of the paired-sample t-tests on all the nine factors have been reported in greater detail in another paper by the same author (Yeung, 2016). 


\subsubsection{Qualitative Data Collection}

In addition to the quantitative data collected with the questionnaires, qualitative data were also collected from the whole group via the open-ended questions in the questionnaire and the self-assessment forms from the three writing tasks and writing journals from individual students in each group.

The open-ended questions in the questionnaire and the self-assessment forms were designed to elicit information corresponding to the various aspects of learner autonomy in the theoretical framework, such as whether they learnt to write on their own (reflecting motivation), whether they planned and revised their writing (reflecting use of writing strategies), and how they evaluated their writing (reflecting metacognitive knowledge). The responses collected were categorized and counted for comparison within groups and between groups. Data collected from the writing journals were analyzed qualitatively to provide evidence for triangulation with other data sources.

Data were also collected from the teachers through in-depth interviews (once before the programme, once after the programme and once after each writing task) and observations of all their writing lessons and a few other non-writing lessons. The aim was to find out whether differences in teaching beliefs and practices may affect the implementation and thus effectiveness of the approach.

\subsubsection{Case Studies}

Five students from Sub-study 2, two from the NET Group and three from the LET Group, were invited to participate in case studies. In the case studies, semi-structured interviews were conducted before and after the writing programme to find out about the participants' approaches to writing and reflections on the learning of writing. The participants were also interviewed individually after each of the writing tasks to elicit the strategies they had used during the writing and revision process. In these individual post-writing interviews, the participant was asked to look at his/her own drafts once again to stimulate recall of the writing process.

All the drafts of the three writing tasks completed by the cases were collected for analysis. The revisions, particularly the quantity and quality of the self-initiated revisions on the drafts were examined as they were considered to be an indicator of the student writer's effort to take charge of the writing process, thus suggesting writer autonomy. Data collected from the case study participants' self-assessment forms and writing journals were analyzed qualitatively and used to corroborate with data from the individual interviews and other supporting data. The interviews were mainly conducted in the participants' L1 (Cantonese), and all the participants in the study including the case study participants were given the liberty to use their L1 in their writing journals and all the forms if they had difficulty expressing themselves fully in English. All the data were then translated into English for reporting.

Informed consent to use the data collected for research purposes was sought from all the participants at the beginning of the study, and it was made clear to them that they had the right to withdraw from the study anytime.

\section{Findings and Discussion}

This report will discuss the major findings of the study, with particular focus on the comparison of the changes of the two groups in Sub-study 2. Data from two of the case studies from the NET Group and the LET Group, identified as Polly and Kelly respectively, will be used to provide more detail at the individual level and to provide insight into how the various components of the process writing programme contributed to such changes.

\subsection{Common Changes After the Writing Programme}

\subsubsection{Decrease in Dependence on the Teacher After the Programme}

There was evidence to suggest that the students became less reliant on the teacher after the programme. In all three groups the mean score of the factor of Degree of Dependence on the Teacher showed a decline ranging from 0.34 to 0.47 at 0.05 level of significance (Table 1), suggesting that in all the three classrooms the process writing programme had the effect of reducing the students' dependence on the teacher. 
Table 1. Changes of the mean scores of the factor of degree of dependence on the teacher in the two sub-studies

\begin{tabular}{|c|c|c|c|c|c|c|c|c|}
\hline & \multicolumn{5}{|l|}{ Paired Differences } & \multirow{3}{*}{$\mathrm{t}$} & \multirow{3}{*}{$\mathrm{df}$} & \multirow{3}{*}{$\begin{array}{l}\text { Sig. } \\
\text { (2-tailed) }\end{array}$} \\
\hline & \multirow{2}{*}{$\begin{array}{l}\text { Change in } \\
\text { Mean (Post-Pre) }\end{array}$} & \multirow{2}{*}{ Std. Deviation } & \multirow{2}{*}{$\begin{array}{l}\text { Std. Error } \\
\text { Mean }\end{array}$} & \multicolumn{2}{|l|}{$95 \% \mathrm{CI}$} & & & \\
\hline & & & & Lower & Upper & & & \\
\hline $\begin{array}{l}\text { Sub-study } 1 \\
(n=30)\end{array}$ & -.36 & .81 & .15 & .05 & .66 & 2.4 & 29 & .022 \\
\hline Sub-study 2 & & & & & & & & \\
\hline $\begin{array}{l}\text { The NET Group } \\
(\mathrm{n}=19)\end{array}$ & -.34 & .64 & .15 & .03 & .65 & 2.3 & 18 & .032 \\
\hline Sub-study 2 & & & & & & & & \\
\hline $\begin{array}{l}\text { The LET Group } \\
(\mathrm{n}=21)\end{array}$ & -.47 & .81 & .18 & .09 & .85 & 2.6 & 19 & .019 \\
\hline
\end{tabular}

We can see this growing independence from the teacher in the case of one of the case studies, Kelly from The LET Group. Before the implementation of the process approach, Kelly said that she needed the teacher's language input:

...... my standard may not be high enough. If the teacher doesn't give me vocabulary items for reference, I may find it difficult to write.

However, she started to enjoy the freedom she had in the writing process and in her last writing journal entry, she actually expressed her dislike of the teacher's control:

In fact, I don't quite like the teacher to give us hints on a writing topic. This would limit my thoughts, making me unable to rely on my own ideas in writing. I realize I am the master of my own writing, and the content of my writing is mine, so I can write whatever I like.

Kelly's changes suggested that the writing programme had helped her develop her independence in writing.

\subsubsection{Greater Self-Sufficiency in Writing}

Findings collected from the open-ended questions in the questionnaire largely supported the findings from the questionnaires. In addition to becoming less dependent on the teacher, the students' responses to the question about what they would do when faced with difficulties in writing suggested a decrease in the tendency to seek help from others (Table 2).

Table 2. Counts of mentions of sources of help in face of difficulties in writing (In response to the open-ended question "When you come across difficulties while writing, what do you do?")

\begin{tabular}{|c|c|c|c|c|c|c|}
\hline \multirow{2}{*}{ Source of help } & \multicolumn{3}{|c|}{ The NET Group } & \multicolumn{3}{|c|}{ The LET Group } \\
\hline & Pre-test & Post-test & Change & Pre-test & Post-test & Change \\
\hline Peers & 14 & 11 & $-3(21.4 \%)$ & 14 & 13 & $-1(7.1 \%)$ \\
\hline The teacher & 13 & 8 & $-5(38.5 \%)$ & 13 & 6 & $-7(53.8 \%)$ \\
\hline $\begin{array}{l}\text { Specific family members } \\
\text { or friends }\end{array}$ & 8 & 2 & $-6(75 \%)$ & 5 & 2 & $-3(60 \%)$ \\
\hline $\begin{array}{l}\text { Others } \\
\text { (anyone who can help) }\end{array}$ & 0 & 2 & +2 & 0 & 2 & +2 \\
\hline Total & 35 & 23 & $-12(34 \%)$ & 32 & 23 & $-9(28 \%)$ \\
\hline
\end{tabular}

This growing self-sufficiency was accompanied by the heightened reflectivity during the writing, which could be reflected by the quality and quantity of some students' self-initiated revisions over the tasks as discussed below.

\subsubsection{Development in Metacognitive Knowledge}

Evidence of growth in metacognitive knowledge was found not only among the cases but also in the writing journals kept other participants in the classes. The following entries in the writing journal by a participant from the LET Group illustrate the gradual development of metacognitive knowledge over the course of the study: 
Entry 1

I feel my writing contains many mistakes. I feel the ending is very bad. I think I can be good at writing the ending. I should work more on writing the ending.

Entry 2

My writing is very boring. I don't know how to make my writing fun, how to make it good. I think I need to read others' writings to make my writing good. I need to make a real effort!

Entry 3

My writing has not been good. Sometimes I think of words to use but I don't know how to put them in sentences, so I can't express my ideas. I hope I can increase my understanding of English sentences.

Entry 4

I will read more articles and books, and even the lyrics of English songs. I have liked listening to songs ever since I was a child, including Chinese, English and Japanese songs, and I would be able to sing them after a while, but I seldom read the lyrics. Even though I may not learn much about sentences through lyrics, I would at least learn more words from them.

\section{Entry 5}

I need to use more conjunctions and new words in my writing. Some sentences need to be presented better for better expression, and I need to check the dictionary more often and read to increase my vocabulary.

These entries evolve from more general remarks about the learner's own writing (e.g. "very bad", "very boring") to more detailed and specific reflections (e.g. "I need to use more new words and conjunctions"), revealing the growth in the learner's knowledge of English learning and writing and her understanding of her own weaknesses over time.

\subsection{Roles That the Various Components of the Process Writing Approach Played in Effecting Changes}

In addition to changes towards a higher level of learner autonomy in writing, findings from the study also help illuminate the roles of the various components of the process writing approach in effecting such changes. Exploration of the writing process of the cases in this study provided some insight into how the multiple-draft approach, with the components of teacher and peer feedback, facilitated the development of autonomous skills and attitudes.

\subsubsection{Multiple-Draft Process Providing the Opportunity to "Think More" About Writing}

First of all, the multiple-draft revision process is a prime component that fosters reflectivity. With the reviewing process formalized in multiple drafts, students would have the opportunity to improve their writing by spotting errors and adding details even in the absence of feedback from others. In the final interview, Kelly discussed how she benefited from the drafting and revision process, saying "now there are more steps, I think more and the content is richer". Evidence of sustained effort to revise a piece of writing across drafts with self-feedback was also found in the case of Polly, who mentioned that she had to "think a lot" over the drafting and revision process. For example, in Task 2, Polly did not stop her revision in the second draft, resulting in a final draft that is better organized:

Second draft:

Everyday I go to school by bus. I am in Form 1C. My favourite subject is Music. I also like P.E. Our class teacher is called Miss Leung. She teaches us Maths. She is very kind, too. My school starts at 8:15 AM. So I usually leave home at 6:40am.

Final draft:

Everyday I go to school by bus. My school starts at 8:15am. So I usually leave home at 6:40 am. I am in Form 1C. My favourite subject is Music because I love singing. Our class teacher is called Miss Leung. She teaches us Maths.

The revised version is better organized as it starts with the more general and narrows down to the more specific details, and the first three sentences share the same theme and so are more coherent. This kind of revision over drafts demonstrated how the multiple-draft approach allowed time and opportunity for reflection on writing. In other words, reflectivity during the writing process was boosted. 


\subsubsection{Peer Feedback Prompting Self-Reflection and Self-Initiated Revisions}

One important contribution of peer feedback to the development of learner autonomy is that it inspires self-reflection and self-initiated revisions. Some self-initiated revisions were found to have been inspired by peer feedback. When asked why she added two sentences in her revised draft in the first writing task, Kelly said:

Because when I read Fion's writing, I gave her feedback. She said her father is fun, and I asked her to give some examples. Then I thought about my own writing. I talked about my brother, and I thought I should also write more about him, so I added these two sentences.

Later in the interview she also mentioned that she noticed that her reviewer often forgot the ending "s", which made her become more aware of this problem and try to avoid it in her own writing. These examples show that peer feedback could serve as an input for self-feedback, which indirectly inspires self-reflection and revision.

\subsubsection{Review Process Facilitating the Growth of a Sense of Ownership}

Peer feedback was also found to facilitate the development of learner autonomy in writing in other important ways. The peer review process could foster the learners' sense of ownership of their writing. For example, with a heightened sense of ownership of her writing, Kelly developed an interesting strategy to safeguard her ideas:

If I have a very special idea, instead of developing it in full in the initial drafts, I would only write it down briefly... Even though they (the reviewers) might copy my key idea, they would not be able to take the whole of it.

It can be argued that the peer review exercise may help inspire writers' inner drive to champion their own ideas and therefore contribute to the development of an important trait of autonomous writers.

\subsubsection{Engagement in the Process Fostering Self-Competence and Intrinsic Motivation}

In some of the cases, the multiple-draft process approach contributed to the increase in fluency in generating and evaluating ideas and as a result, enhanced confidence and eventually motivation in learning writing. As Kelly admitted, the drafting and revising process stimulated her to think a lot. It is through such countless cognitive cycles that metacognitive knowledge gradually develops (Flavell, Miller, \& Miller, 2002), and Kelly's growth in metacognitive knowledge helped her become more effective in planning and idea generation in the writing process, thus the fluency. The actual development in her fluency in writing gave her a sense of self-competence. As she said in the final interview:

I think I can think more swiftly now... Give me a topic, and I can easily and quickly think up many things to write about it.

Her engagement in the writing process seemed to be a source of enjoyment:

Writing is hard, and I have to rack my brain each time; but when the task is done, I feel gratified.

As Kelly's interest in English writing grew, her motivation to carry on with her exploration of writing appeared to be more intrinsic in nature. In her last journal entry, much more emphasis was put on the gratification she got from the writing process and the pride she took in composing a good piece of writing:

I used to find writing boring at times, but now I find it much fun because during the process, I get really into it, thinking about how to make the content rich and riveting. When I am done, I would also feel proud, gratified and happy.

\subsubsection{Interaction With Reviewers Fostering Audience Awareness}

In addition to the increased self-confidence and interest in writing and a stronger sense of ownership of her writing, Kelly also developed some craving for reader responses. As the semester progressed, Kelly was not satiated with feedback only on the content or language use. She also wanted to know how the teacher and the others felt about her writing, and how to appeal to them. In the last interview, she agreed with the researcher that she started to need an audience:

Kelly: ...If I got an audience, and if they can give me some ideas which I can pick and choose for incorporation in my writing, then I think my writing would have more substance.

Researcher: What do you expect to get from your audience?

Kelly: Their feelings (about my writing). And when I know how they feel, I can look at my writing to see what I could do about it to appeal to them and also what ideas I would like to communicate to them.

Such audience awareness, which is characteristic of more skilled writers (Hayes \& Flower, 1980) and has long been regarded as a key aspect of writing competence (Berkenkotter, 1981), probably stemmed from the interaction with her reviewers (Pritchard \& Honeycutt, 2007). Kelly's case therefore illustrates how the process 
approach may help learners develop not only autonomous skills and attitudes but also competence in writing.

\section{Conclusion}

It seems as if these young ESL learners showed changes that reflected development in their autonomy in writing after they had experienced the process writing approach. In particular the following changes were noted:

Decrease in dependence on the teacher;

Increased self-reliance in writing;

Enhanced reflectivity on the writing process;

Growth in metacognitive knowledge.

In some cases the approach also contributed to the development of positive attitudes towards writing, motivation to learn to write and the feeling of competence in this group of teenage learners. These could all be signs of development of learner autonomy in writing. In other words, the process approach was found to facilitate growth in various aspects of learner autonomy in the area of writing in regular secondary school classrooms in Hong Kong.

It is worth noting that despite having teachers from different cultural backgrounds and thus inevitable differences in teaching beliefs and styles (Zhou \& Pedersen, 2011), both the NET and LET Groups demonstrated similar changes through the writing programme. Overall, the study shows that cultural and contextual differences may affect the outcomes of a pedagogical approach to a certain extent, but not to the point of offsetting all its benefits. Whatever differences may exist, as long as teachers can attend to students' affective and cognitive learning needs and develop suitable pedagogical techniques, they may still be able to increase both the students' commitment to learning and their chances of success in it (Mantle-Bromley, 1995).

The study therefore provides an affirmative answer to the question as to whether young ESL learners would show changes that reflect development in learner autonomy in writing after being taught writing using a peer-review multiple-draft process writing approach. Findings from this study also provide empirical evidence in support of the proposition that one of the greatest strengths of the process writing approach as a pedagogy lies in its potential to foster learner autonomy, particularly among young learners. With the recognition of such a strength, teachers may adopt the approach in their writing classrooms with the development of learner autonomy as an intended learning outcome. By nurturing such autonomous attitudes as motivation and self-confidence, the process approach may also directly or indirectly lead to improvement in writing performance, as motivational variables such as attitudes towards writing and self-efficacy have been found to be predictive of the quality of writing among young learners (Graham, Kiuhara, \& Fishman, 2017; Pajares, 2003).

In addition to providing empirical evidence of whether the process approach can foster learner autonomy among young learners with emergent writing ability, the study also brings up some issues for further research. One such issue is the possibility of the existence of developmental stages in learner autonomy. While some participants in this study showed some noticeable changes after the writing programme, others showed less development; while all the groups started to become less dependent on the teacher in writing, their changes in other aspects of learner autonomy seemed to be less significant. This may suggest staggering development of various attributes of learner autonomy, possibly with independence from the teacher being the first trait to emerge. As learners become independent of the teacher, do they automatically take up the responsibility for their own learning? Development may also be affected by other factors, such as individual personalities and attitudes and their interactions with contextual factors. Further longitudinal research involving larger samples in a cross-cultural perspective would be useful for validating and substantiate findings in this study and address some of the issues raised above. Inquiry along this line will help practitioners make more informed pedagogical decisions and understand better how learner autonomy can be nurtured and measured.

\section{References}

Benson, P. (1996). Concepts of autonomy in language learning. In R. Pemberton (Ed.), Taking control: Autonomy in language learning. Hong Kong: Hong Kong University Press.

Benson, P. (2011). Teaching and researching autonomy in language learning (2nd ed.). London: Routledge.

Benson, P. (2009). Making sense of autonomy in language learning. In R. Pemberton, R. Toogood, \& A. Barfield (Eds.), Maintaining control: Autonomy and language learning. Hong Kong: Hong Kong University Press. https://doi.org/10.5790/hongkong/9789622099234.003.0002

Berkenkotter, C. (1981). Understanding a writer's awareness of audience. College Composition and 
Communication, 32, 388-391. https://doi.org/10.2307/356601

Bitchener, J., \& Ferris, D. (2012). Written Corrective Feedback in Second Language Acquisition and Writing. New York: Routledge. https://doi.org/10.4324/9780203832400

Casanave, C. P. (2004). Controversies in second language writing: Dilemmas and decisions in research and instruction. Ann Arbor: University of Michigan Press. https://doi.org/10.3998/mpub.9691

Cotterall, S. (1995). Readiness for autonomy: Investigating learner beliefs. System, 23(2), 195-205. https://doi.org/10.1016/0346-251X(95)00008-8

Cresswell, A. (2000). Self-monitoring in student writing: developing learner responsibility. ELT Journal, 54(3), 235-244. https://doi.org/10.1093/elt/54.3.235

Curtis, A. (2001). Hong Kong student teachers' responses to peer group process writing. Asian Journal of English Language Teaching, 11, 129-143.

Dam, L. (1995). Learner autonomy 3: From theory to classroom practice. Dublin: Authentik.

Dickinson, L. (1992). Learner training for language learning. Dublin: Authentik Language Learning Resources.

Flavell, J. H., Miller, P. H., \& Miller, S. A. (2002). Cognitive development (4th ed.). Upper Saddle River, NJ: Prentice Hall.

Graham, S., Harris, K. R., Kiuhara, S. A., \& Fishman, E. J. (2017). The relationship among strategic writing behavior, writing motivation, and writing performance with young, developing writers. The Elementary School Journal, 118(1), 82-104. https://doi.org/10.1086/693009

Hayes, J. R., \& Flower, L. S. (1980). Identifying the organization of writing processes. In L. N. Gregg, \& E. R. Steinberg (Eds.), Cognitive processes in writing (pp. 3-30). Hillsdale, N.J.: Lawrence Erlbaum Associates.

Holec, H. (1981). Autonomy and foreign language learning. Oxford: Pergamon Press.

Hyland, F. (2000). Teacher management of writing workshops: Two case studies. Canadian Modern Language Review, 57(2), 272-294. https://doi.org/10.3138/cmlr.57.2.272

Hyland, K. (2002). Teaching and researching writing. Harlow: Longman.

Hyland, K. (2003). Genre-based pedagogies: A social response to process. Journal of Second Language Writing, 12(1), 17-29. https://doi.org/10.1016/S1060-3743(02)00124-8

Hyland, K., \& Hyland, F. (2006). Feedback on second language students' writing. Language Teaching, 39, 83-101. https://doi.org/10.1017/S0261444806003399

Katznelson, H., Perpignan, H., \& Rubin, B. (2001). What develops along with the development of second language writing? Exploring the "by-products". Journal of Second Language Writing, 10(3), 141-159. https://doi.org/10.1016/S1060-3743(01)00040-6

Little, D. (1991). Learner autonomy: Definitions, issues and problems. Dublin: Authentik Language Learning Resources.

Little, D. (1997). Language awareness and the autonomous language learner. Language Awareness, 6(2-3). https://doi.org/10.1080/09658416.1997.9959920

Little, D. (2004). Constructing a theory of learner autonomy: Some steps along the way. Future Perspectives in Foreign Language Education, 101, 15-25.

Little D. (2007). Introduction: Reconstructing learner and teacher autonomy in language education. In A. Barfield, \& S. H. Brown (Eds), Reconstructing autonomy in language education: Inquiry and innovation (pp. 1-12). Palgrave Macmillan, London. https://doi.org/10.1057/9780230596443_1

Mantle-Bromley, C. (1995). Positive attitudes and realistic beliefs: Links to proficiency. The Modern Language Journal, 79(3), 372-386. https://doi.org/10.1111/j.1540-4781.1995.tb01114.x

Matsuda, P. K. (2003). Process and post-process: A discursive history. Journal of Second Language Writing, 12(1), 65-83. https://doi.org/10.1016/S1060-3743(02)00127-3

Oxford, R. L. (1990). Language learning strategies: What every teacher should know. Boston: Heinle \& Heinle.

Oxford, R. L. (2003). Toward a more systematic: Model of L2 learner autonomy. In D. Palfreyman, \& R. C. Smith (Eds.), Learner autonomy across cultures: Language education perspectives (pp. 75-91). London: Palgrave Macmillan. https://doi.org/10.1057/9780230504684_5 
Pajares, F. (2003). Self-efficacy beliefs, motivation, and achievement in writing: A review of the literature. Reading \& Writing Quarterly, 19, 139-158. https://doi.org/10.1080/10573560308222

Pedhazur, E. J., \& Schmelkin, L. P. (1991). Measurement, design, and analysis: An integrated approach. Hillsdale, NJ: Lawrence Erlbaum Associates.

Pritchard, R. J., \& Honeycutt, R. L. (2007). Best practices in implementing a process approach to writing. In S. Graham, C. A. MacArthur, \& J. Fitzgerald (Eds.), Best practices in writing instruction (pp. 28-49). New York: Guilford.

Sasaki, M. (2004). A multiple-data analysis of the 3.5-year development of EFL student writers. Language Learning, 54(3), 525-582. https://doi.org/10.1111/j.0023-8333.2004.00264.x

Scharle, Á., \& Szabó, A. (2000). Learner autonomy: A guide to developing learner responsibility. Cambridge: Cambridge University Press.

Sheerin, S. (1997). An exploration of the relationship between self-access and independent learning. In P. Benson, \& P. Voller (Eds.), Autonomy and independence in language learning (pp. 54-65). London: Longman.

Thomsen, H., \& Gabrielsen, G. (1991). Cooperative teaching-learning: Beginners in the 5th form [Video]. Copenhagen: Danmarks Lærerhøjskole.

Wenden, A. (1991). Learner strategies for learner autonomy: Planning and implementing learner training for language learners. New York: Prentice Hall.

Wenden, A. (1998). Metacognitive knowledge and language learning. Applied Linguistics, 19(4), 515-537. https://doi.org/10.1093/applin/19.4.515

Yeung, M. (2016). Exploring the construct of learner autonomy in writing: The roles of motivation and the teacher. English Language Teaching, 9(8), 122-139. https://doi.org/10.5539/elt.v9n8p122

Zamel, V. (1983). The composing processes of advanced ESL students: Six case studies. TESOL Quarterly, 17(2), 165-187. https://doi.org/10.2307/3586647

Zhou, P., \& Pedersen, C. (2011). Understanding cultural differences between Western and Confucian teaching and learning. In W. Midgley, M. A. Tyler, P. A. Danaher, \& A. Mander (Eds.), Beyond binaries in education research (pp. 161-175). New York: Routledge.

\section{Appendix A}

\section{Sample Items/Questions from the Questionnaire}

Questions about learner background

Gender $\square$ male $\square$ female

Age

Place of birth

First language spoken at home

Number of years of schooling in Hong Kong

Number of years of English learning

Have you studied away from Hong Kong?

\section{Sample items from Section 1}

I seldom write in English except for school assignments, tests and exams.

I like English writing.

Learning English writing will help me find jobs in future.

When we write, the teacher should provide model essays as well as vocabulary and sentence patterns related to the topic for our reference. 


\section{Sample items from Section 2}

I plan before I write.

I use reference tools like dictionaries and grammar books when I write.

I always make drafts when doing writing tasks.

Even if the teacher does not ask me to, I revise my own writing until I am satisfied with it.

\section{Sample items from Section 3}

I have clear and concrete learning goals in writing.

I clearly know my strengths and weaknesses in the area of writing.

When I do English writing, I practise using different sentence patterns, vocabulary and expressions.

I look for ideas for writing outside the writing class

Open-ended questions used

How do you write? Please briefly describe your whole writing process.

When you come across difficulties while writing, what do you do?

Do you use any methods or tools to help yourself write better while doing a writing task? What is it/are they?

What aspects of your writing do you think you need to work more on? Why?

Do you have any clear goals in the learning of writing? What is it/are they?

Do you have any plans to improve your writing? If so, what is your plan? Have you started to carry it out?

Do you know how to assess your own writing? What are your criteria?

\section{Appendix B}

\section{Sample Prompts Used in the Self-assessment Forms}

Based on the rubric, I rate my writing out of 5 because

I did particularly well in

I need to improve in

In this writing task, I have learnt

The following is how I feel/felt about this writing task:

Reminders for myself:

\section{Copyrights}

Copyright for this article is retained by the author(s), with first publication rights granted to the journal.

This is an open-access article distributed under the terms and conditions of the Creative Commons Attribution license (http://creativecommons.org/licenses/by/4.0/). 